\title{
Kant On Moral Agency and Women's Nature
}

\author{
MARI MIKKOLA
}

Humboldt-Universität zu Berlin

\begin{abstract}
Some commentators have condemned Kant's moral project from a feminist perspective based on Kant's apparently dim view of women as being innately morally deficient. Here I will argue that although his remarks concerning women are unsettling at first glance, a more detailed and closer examination shows that Kant's view of women is actually far more complex and less unsettling than that attributed to him by various feminist critics. My argument, then, undercuts the justification for the severe feminist critique of Kant's moral project.
\end{abstract}

\section{Introduction}

Feminist commentators have not viewed kindly Kant's remarks about women in his Observations on the Feeling of the Beautiful and Sublime (O) and the Anthropology from a Pragmatic Point of View (A). As Barbara Herman puts it, these remarks have made Kant the modern moral philosopher feminists find most objectionable (2002: 54). Many of Kant's remarks are unflattering and disquieting, for sure. He describes women as coquettes $(A 305)$ and writes that they have 'a beautiful understanding' due to which '[l]aborious learning or painful pondering, even if a woman should greatly succeed in it, destroy the merits that are proper to her sex' $\left(\mathrm{O}_{78}\right) .{ }^{\mathrm{I}}$ Kant mocks intellectual women, stating that they 'might as well even have a beard' $\left(\mathrm{O}_{78}\right)$ and he accuses scholarly women of being fraudulent: such a woman uses her books 'in the same way as her watch ... which she carries so that people will see that she has one, though it is usually not running or not set by the sun' $(A$ 307). For many feminist readers, Kant's remarks in the Observations about women's moral conduct are a particular sticking point. These remarks imply that Kant took women to be seriously morally deficient: although women have 'many sympathetic sensations, goodheartedness, and compassion' (O 77), Kant infamously writes that '[w]omen will avoid the wicked, not because it is unright (unrecht), but 
because it is ugly; and virtuous actions mean to them such as are morally beautiful' (O 77). He continues:

Nothing of duty, nothing of compulsion, nothing of obligation! Woman is intolerant of all commands and morose constraint. They do something only because it pleases them, and the art [of moral education] consists in making only that please them which is good ... I hardly believe that the fair sex is capable of principles ... in place of it Providence has put in their breast kind and benevolent sensations. (O 77)

In the light of such comments, women's apparent moral deficiency comes down to them acting from inclinations, when they should act from rational moral principles. Women are not morally deficient in that they simply fail to do what they dutifully ought to do. Rather, they are deficient in that when women do what they ought to do, nonetheless, they fail to do so from the right reasons. Here is a representative example from Susan Moller Okin of reading Kant in this way:

\begin{abstract}
What clearly happens to women [in Kant's Observations] is that they become defined right out of that category of 'all rational beings as such,' to whom Kant has said his moral theory must apply ... When Kant asserts categorically that, for women, there is to be [Nothing of duty, nothing of compulsion, nothing of obligation], we know that their dehumanization is complete ... [I]f women are, and should be, characterized not by rationality but by that sensibility and delicacy of feeling that makes them charming wives and devoted guardians of the sentimental family, then a moral theory that is to apply not only to men but to 'all rational beings as such' has no need to be applicable to women. (I982: 82)
\end{abstract}

Okin is not alone. Others have also criticized Kant for taking women to fall short of 'the practical reason demanded by the predisposition to morality' (Rumsey I997: I3I) because he took women to act solely from natural impulses (Kleingeld I993: I36) - that is, because Kant took women's 'character ... [to be] wholly defined by natural needs' (Schott I997: 323; see also Grimshaw I986: 42-5; Mendus I992; Plumwood I993: 436; Schott I998a, I998b). This charge is usually coupled with another, much stronger, claim: that Kant took women's moral deficiency to be part of their nature. Okin holds that Kant's failure to extend his moral theory to women is due to his view that the differences between 
women and men are 'largely innate' and to his commitment to fostering these differences 'by different educations of the two sexes, lest "the charming distinction" that nature intended between the sexes become blurred' (I982: 8I). Robin May Schott writes that '[w]oman's lack of self-determination, in [Kant's] view, is intrinsic to her nature' (I997: 323) and that, for him, women are consequently incapable of rational thought' (I988: p. viii; see also Antony I998: 63-4; Mendus I992: I80).

Kant's apparently dim view of women as being innately morally deficient has led some commentators to condemn his moral project from a feminist perspective. First, since Kant's moral theory fails to apply to women despite its prima facie universal applicability, Kant's genderneutral language in works like the Groundwork of the Metaphysics of Morals is said to be misleading. What is true of gender-neutral moral agents only turns out to be true of some men and '[b]y ascribing to women a separate virtue, incentive, and vocation, Kant implies that the central tenets of the Critical practical philosophy are not applicable to women' (Kleingeld I993: I36-7). Feminists supposedly have good reasons to doubt that Kant has provided a picture of genuinely universal moral agency and they cannot simply bracket off his noxious remarks about women, insisting that women are not morally deficient: these remarks are said to show that his conception of moral agency is flawed in taking 'the pattern for "normal agency" to be that of the man of [Kant's] time and place' (Rumsey I997: I26). It is not enough to say contra Kant that women fit such a pattern; rather, his views about women undermine the pattern itself in demonstrating that it is deeply androcentric (Sedgwick I990: 7I-2). Second, if women are seriously morally deficient, they will be deficient as autonomous agents; and this is thought to be particularly worrying since autonomy is the source of human dignity on Kant's view. So, despite being an advocate of the Enlightenment 'with strong views about the autonomy and equality of "all human beings", Pauline Kleingeld writes, 'Kant makes crucial exceptions for women ... denying them the capacity for personal autonomy' (I993: I34; see also Schott I998b: 45). Kant is thus said to exclude women from the class of persons, classifying them instead 'as natural serfs or animals ... [In his view] women are not human beings' (Schröder 1997: 296; see also Pateman I988: I7I). If Kant's remarks about women have these consequences, feminists certainly have a cause for concern.

Now, one might immediately protest that drawing such conclusions while focusing on one of Kant's early pre-Critical works is unfair. With this in mind, one might be tempted to suggest that perhaps Kant 
changed his view from the Observations of 1764 to the Groundwork of I785, no longer taking women to be morally deficient by the later date. This suggestion is usually rejected, however, because the Anthropology that was published in 1798 expounds views that are similar to those found in the Observations (see $O_{76-96}$ and $A$ 303-I I for these views). And this is taken to demonstrate continuity in Kant's thinking on women's character even by Marcia Baron who holds the sympathetic view that perhaps Kant's remarks are not 'quite so deplorable as critics make them out to be' (I997: I66). ${ }^{2}$ As I see it, Kant's claims in the Observations and Anthropology are sufficiently similar to undermine the suggestion that he substantially altered his view of women over time. Nonetheless, I agree with Baron that they are not quite as deplorable as many feminist critics make them out to be. Here I will argue that, although his remarks are unsettling at first glance, a more careful examination shows that Kant's view of women is far more complex and less unsettling than that attributed to him by various feminist commentators. In particular, I will do so by focusing on the issue of women's supposed moral deficiency. In section 2, I will discuss how women are meant to be morally deficient and show that pointing this out is actually very tricky: there are a number of ways in which we could understand the moral deficiency women supposedly exhibit and Kant's own remarks are far from decisive, being vague and inconsistent. I go on to suggest that only one of the possible ways to understand women's moral shortcomings is seriously problematic from a feminist perspective: if Kant took women to be innately incapable of morality. In section 3 , however, I will argue that the prospects of showing he was committed to this view are not good. This, then, undermines the justification for a strong feminist condemnation of Kant's moral project.

\section{How are Women Morally Deficient?}

The first, quick and dirty, way to understand women's supposed moral deficiency involves pointing out that women have a desire to avoid moral ugliness and that this undercuts their actions having moral worth. Kant's view of moral worth seems straightforward enough: actions that accord with duty and have been performed from duty have it, whereas dutiful actions not performed from duty but from some non-moral motives (like self-interest or immediate inclination) lack it. This is because

an action from duty has its moral worth ... in the maxim in accordance with which it is decided upon, and therefore does not depend upon the realization of the object of the action but 
merely upon the principle of volition in accordance with which the action is done without regard for any object of the faculty of desire. ( $G$ 399-400)

So, one might point out that in Kant's view women's actions are not devoid of 'regard for an object of the faculty of desire', because he takes women to have an inclination to avoid moral ugliness. Since morally worthy actions should exclude the presence of all such non-moral motives, Kant's remarks show that women's actions lack moral worth. Women, then, are morally deficient because they have an immediate inclination to perform morally beautiful actions.

However, this 'if inclination, no moral worth' argument attributes to Kant (what Paton (I97I) calls) 'the absurd view' of moral worth, which takes duty and inclinations to be mutually exclusive. Simply pointing out that women desire to perform morally beautiful actions so that Kant took them to fall short of what is required for morality, comes dangerously close to this view. Numerous writers have persuasively debunked it (e.g. Baron I995; Galvin I991; Henson 1979; Herman I993; Korsgaard 1996; Paton 197I; Sorell 1998; Stratton-Lake 2000; Tannenbaum 2002; Wood I999, 2008). For instance, Baron claims that on Kant's view the 'presence of inclination is consistent with the action being done from duty, and thus having moral worth' (I995: I 52). ${ }^{3}$ It is instructive to see why Kant was not committed to the absurd view, in order to clarify his notion of moral worth. In his (rather infamous) Groundwork examples, Kant sets out the conditions for morally worthy actions. Actions that accord with duty but have been performed from 'a self-seeking purpose' have no genuine moral worth ( $G$ 397). This is known as the shopkeeper example. The shopkeeper who does not charge inexperienced customers more in order to retain a reputation as an honest shopkeeper acts dutifully. But they do so only out of self-interest, thereby acting in a way that compromises moral worth. Specifically, the problem is that the shopkeeper's actions are dutiful merely 'for circumstantial reasons' (Herman I993: 3). Their motive for acting (self-interest) is insufficient to guarantee that dutiful actions are performed. So a condition of moral worth is that one's actions are performed non-accidentally.

Moral worth is also absent from the dutiful actions of the 'sympathetic man', who has 'an immediate inclination' to perform them ( $G$ 397). In the Groundwork, Kant claims that beneficence is a duty; but someone who is naturally sympathetic may perform dutiful beneficent actions 
from an immediate inclination to spread joy. In such a case, however much their action 'may conform with duty and however amiable it may be, [it] has nevertheless no true moral worth' ( $G$ 398). The reason for the lack of moral worth is not the same as with the shopkeeper (that their dutiful actions are accidental); instead, it is that the sympathetic man does not see his beneficent action as morally required. Sympathetic inclinations are morally precarious in that they may not prevent one from acting contrary to duty; and this is because in acting from an immediate inclination the moral requiredness of the action is not of concern to the agent. As Herman puts it, 'while sympathy can give an interest in an action that is (as it happens) right, it cannot give an interest in its being right' (I993: 5I). The second condition of moral worth, then, is that one's action is performed from a concern about its moral requiredness. The sympathetic man example is instructive in further demonstrating why the absurd view of moral worth should be rejected. Baron (1995) rightly points out that Kant takes there to be a difficulty in saying whether one has acted from duty 'when an action conforms with duty and the subject has, besides, an immediate inclination to it' ( $G$ 397). But, if duty and inclinations simply are mutually exclusive, this difficulty should not arise. Quite simply: if the absurd view holds, the presence of corroborating inclinations is enough to show that an action has not been performed from duty. In acknowledging that there is this difficulty, Baron persuasively claims that Kant clearly rejects the absurd view. ${ }^{4}$

The upshot of the above discussion is this: pointing out that women have an inclination to avoid moral ugliness does not yet account for their supposed moral deficiency. This is because in general pointing out that agents have inclinations, like sympathetic feelings, does not yet account for any moral deficiency given that the absurd view of moral worth is false. However, perhaps we can refine the above quick and dirty account by considering more carefully when one's action is morally worthy. According to Herman, moral worth depends on one's actions being non-accidental and performed because they are morally required (1993: 3-5; see also Korsgaard 1996: 206-7). If she is right, these conditions should be present in the extended sympathetic man example where his actions have moral worth. Kant asks us to imagine that the above-mentioned sympathetic character loses the inclination to act beneficently because his mind has become clouded by personal grief. '[S] uppose that now', Kant writes, 'when no longer incited to [act beneficently] by any inclination, he nevertheless tears himself out of this deadly insensibility and does the action without any inclination, simply 
from duty; then the action first has its genuine moral worth' ( $G$ 398). Herman's conditions for morally worthy actions are satisfied: the agent's beneficence is non-accidental and something that he saw as being morally required. These conditions mark the difference between the action being in accordance with duty (having legality) and being performed from duty (having morality). The former 'is possible even if the inclinations alone have been the determining grounds of the will'; but morality 'or moral worth, must be placed solely in this: that the action takes place from duty, that is, for the sake of the law alone' (CPractR 8I) - the action is performed because it is morally required. ${ }^{5}$

On this more refined account, women's moral deficiency seems to come down to their dutiful actions having legality, but not morality. But why precisely do they lack morality? And what (if anything) is problematic about this? Kant's remarks about women suggest that when they act dutifully their actions do not lack moral worth because they are accidental. He writes that women have 'many sympathetic sensations, goodheartedness, and compassion' ( $O$ 77) - they have an immediate inclination to be beneficent just like the sympathetic man. And having such immediate inclinations guarantees that women act beneficently when they see the need to and that their dutiful actions are not simply down to 'circumstantial reasons', like those of the shopkeeper. However, Kant goes on to write that 'virtuous actions mean to [women] such as are morally beautiful' $\left(O{ }^{8} \mathrm{I}\right)$, suggesting that women fail to see dutiful actions as being morally required. And this accounts for why their actions lack moral worth: women do not concern themselves with the moral requiredness of their actions. But why is this a problem? Briefly put: the problem is that legal actions elicit moral approval but not esteem, which is reserved for actions that have moral worth. Actions that accord with duty but have not been performed from duty (like those of the sympathetic man before he lost the natural beneficent inclinations) elicit the former: as Kant puts it, they deserve moral praise and encouragement $(G 398)$. Actions that accord with duty and have been performed from duty, however, have a special moral value beyond that of approval: esteem $(G 398)$. The problem with women, then, is the failure of their actions to elicit esteem. Still, this raises a further issue: what is so special about esteem? There is clearly an important moral difference in simply (say) failing to be beneficent and being beneficent from some immediate inclination: the former evokes moral blame and reproach whereas the latter deserves praise and encouragement (though not esteem). After all, 'we do nothing wrong or contrary to duty [according to Kant] by acting in conformity to duty from other 
[than moral] incentives' (Wood I999: 35; see also Allison I998: 290; Campbell 1983; Henson 1979; Herman 1993; Paton I97I: I4I-2; Stratton-Lake 2000; Wood 2008: 24-30). It is still good to be beneficent from an immediate inclination. Nonetheless, it would be better to be beneficent from duty presumably because this demonstrates that the agent is non-accidentally concerned about their action's moral requiredness, having reflected on this prior to acting - in a sense, morality is an achievement and this makes it more valuable.

So far we have identified the problem with women's moral conduct as being that their actions have legality, but not morality, because women do not see their actions as being morally required. It is important to stress, however, that in so doing women are not acting wrongly - they are not wholly morally lacking in that their actions are still good, though not morally ideal. Still, one might wonder whether there is anything commendable, and much to be reproached, in women's moral conduct if they never perform actions that elicit moral esteem. This might suggest that there is something seriously deficient in women's moral character, although their individual actions are not so problematic. This proposal is based on a view of moral worth like Baron's. She argues that we should not think about moral worth as attaching to individual actions. Rather, it should be understood as 'conduct viewed over a stretch of time, and governed by a commitment which unifies and directs the self' (I984: 220). The special value exhibited by morality concerns one's conduct and how one lives so that ' $[t]$ he definitive feature of someone who acts from duty is her commitment to doing what she really ought to do - and to determining what she ought to do-and this is significant as a long-term, wide-ranging commitment, governing all one does' (Baron I984: 209). Perhaps Kant took women's deficiency to be that they utterly lack this commitment to live their lives doing what they ought to do. ${ }^{6}$

It is far from obvious, though, whether this was Kant's view. His remarks are simply not specific enough for us to conclude that he took women always to be morally indifferent. Granted, Kant does claim that '[w]omen will avoid the wicked, not because it is unright (unrecht), but because it is ugly' and that they are 'intolerant of all commands and morose constraint', doing 'something only because it pleases them' (O 8I). But elsewhere he describes women quite differently:

If one attends to the course of conversation in mixed companies consisting not merely of scholars and subtle reasoners but also of business people or women, one notices that their entertainment 
includes ... arguing ... Now, of all arguments there are none that more excite the participation of persons who are otherwise soon bored with subtle reasoning ... than arguments about the moral worth of this or that action ... Those for whom anything subtle and refined in theoretical questions is dry and irksome soon join in when it is a question of how to make out the moral import of a good or evil action ... and to an extent one does not otherwise expect of them on any object of speculation they are precise, refined, and subtle in thinking. (CPractR I53)

This passage demonstrates just how complex and multifaceted Kant's view of women was, contrary to the claims of many feminist commentators. He certainly does not unequivocally claim that women are always indifferent to morality, although Kant does not clearly affirm that women's moral conduct elicits esteem either. Given this, I hold, it would be precarious simply to conclude that Kant viewed women to have deficient moral characters in the sense discussed, since his remarks are not sufficiently informative.

However, this may not yet vindicate women's moral character: one might wonder whether Kant is nevertheless committed to the view that women find it harder to act from duty in comparison to men. $\mathrm{He}$ accepts that in general acting morally is not easy because 'we everywhere come upon the dear self, which is always turning up; and it is on this that [our actions'] purpose is based, not on the strict command of duty' ( $G$ 407). Perhaps Kant thought that women 'come upon the dear self' more often and more easily than men, given their coquetry and beautiful (rather than noble) understanding. In examining this charge, Kant's remarks about men's moral conduct are instructive. Kant's feminist critics often take him to claim that men qua men are exemplary moral agents. For instance, Rumsey claims that Kant 'models the moral agent on the male-identified qualities of his patriarchal world: autonomy, rationality, independence, detachment, courage, and strength' (I997: I32). Antony and Witt remark that Kant defined 'reason in [his] own male image and denied women full rationality' (2002: p. xvii). By contrast, in the Observations Kant explicitly denies that men are moral agents par excellence. Despite stating that 'I hardly believe that the fair sex is capable of principles', Kant immediately continues: 'and I hope by that not to offend, for these are also extremely rare in the male' (O 8I). Feminists critical of Kant usually cite the former part of this passage but they leave out the part about how extremely rare it is for men to act from moral principles. The view that men are somehow 
perfect moral agents is further undermined by Kant's insistence that everyone is morally deficient in that all rational wills are morally imperfect $\left(G_{4} \mathrm{I} 4\right)$. He claims that '[c] omplete conformity of the will with the moral law is ... holiness, a perfection of which no rational being of the sensible world is capable at any moment of his existence' (CPractR I22). After all, in order to facilitate the 'endless progress toward that complete conformity', Kant postulates the immortality of the soul (CPractR I22). ${ }^{7}$ Whether Kant, nevertheless, took women qua women to be more easily swayed by selfish concerns is not yet shown to be false. But again the problem is that Kant's own remarks are far from definitive and decisive: he simply does not tell us enough in a sufficiently clear manner. At the very least, it is far too simplistic to say that Kant just viewed men qua men to be morally perfect rational agents, and that he took women qua women to be seriously morally deficient. This, I submit, is not supported by Kant's claims about the sexes in the Observations.

Actually, even if Kant took women to be morally deficient in acting more readily from selfish concerns, this may not be as worrying as it might first seem. We must consider the reason for women's moral shortcoming: is it because women's moral education has failed them, or because they are innately incapable of seeing dutiful actions as morally required? If the problem with women is their moral education, this should deflate feminist concerns with Kant's remarks. After all, there would be nothing about women qua women that prevents them from acting morally and an alternative moral education should correct those deficiencies that are due to women's upbringing. By contrast, if Kant's view was that women are innately incapable of morality, feminists have a cause for concern and a serious one at that. However, once again Kant's own remarks are too imprecise to settle these interpretative matters. First, it is not obvious that Kant was committed to the view that women act more readily from selfish concerns; second, even if this was Kant's view, his reasons for holding it are unclear. Nonetheless, I submit that there is sufficient textual evidence to show that Kant was not committed to the view that women are innately incapable of morality. I will argue for this in the remainder of the paper.

\section{Are Women Innately Incapable of Morality?}

Let us take stock of the previous section. There I discussed four different ways to account for what might make women on Kant's view morally deficient: ( $\mathrm{I}$ ) women have an inclination to avoid moral ugliness; (2) women's dutiful actions are not determined by duty; 
(3) women have deficient moral characters in never wholly acting from duty; and (4) women have deficient moral characters, for some reason finding it harder than men to act from duty. I argued that (I) and (2) are too quick and dirty: pointing out that women have inclinations and that their actions have legality is not yet sufficient to show that they are seriously morally lacking in Kant's view. Further, I argued that there is not sufficient textual evidence to support (3) and I questioned the assumption in (4) that men are somehow exemplary moral agents. This section discusses further some issues raised by (4) and specifically focuses on why women might find it harder than men to act from duty. If Kant was committed to this claim, his view is seriously problematic only if he took the difficulties which women face to be due to their innate inability to act from duty. That is, Kant's view of women's moral conduct warrants the severe feminist condemnation of his moral project only if he took women to be by nature incapable of morality. But the prospects of making good this claim are poor. If Kant was committed to it, he must have also been committed to the following. First, that he took women to lack rationality, which is a prerequisite for morality, and to do so innately. Second, that Kant denied women the capacity for morality by denying them human dignity and worth. However, as I will argue next, Kant was not committed to either of these views, although his remarks about women are not entirely enlightened.

\section{Rationality and women's nature}

Consider the charge that Kant took women to lack rationality by nature (e.g. Mendus I992: I80; Okin I982: 8I; Schott I997: 323). Although not in relation to Kant, Louise Antony (2000) has helpfully argued that, usually when one tries to show that we naturally possess or lack some trait, either a deterministic or a normative premise is presupposed. So, if we say that $x$ possesses or lacks some trait by nature, this must be combined with one of the two premises to get the argument off the ground. Either we must presuppose a deterministic premise, whereby what is true of $x$ by nature cannot be changed. In this case, it is downright impossible to change some state of being. Or we must presuppose some normative premise, whereby what is true of $x$ by nature is good for $x$, the wider society, some interested party, etc. (Antony 2000: I2). In this latter case, it is not impossible to change some state of being change is merely seen as undesirable or inappropriate. Now, the account of women's moral deficiency that would make Kant's remarks seriously problematic must involve a deterministic premise: that it is downright impossible to change the fact that women are morally deficient. More specifically, it must involve the deterministic claim that 
women by nature lack what is required for morality: that women lack rationality and it is downright impossible to alter this. However, Kant's remarks do not involve such a premise. At most, they involve a normative claim: although he thought women were capable of rationally setting their own ends, Kant thought it undesirable for them to do so. ${ }^{8}$

To the best of my knowledge, Kant never explicitly claims in the Observations or the Anthropology that women are not rational. Rather, he explicitly characterises both men and women as rational beings, claiming that nature has provided 'the man with greater strength than the woman in order to bring them together into the most intimate physical union, which, insofar as they are still rational beings too, it orders to the end most important to it, the preservation of the species' (A 303). When discussing this passage, Pauline Kleingeld argues that, although Kant apparently claims that both men and women are capable of rationality, he nonetheless thought that women's exercise of reason involves serious deficiencies. And due to these deficiencies 'everything [Kant] says about dignity and vocation of humanity ... applies de facto only to men (males). For these "deficiencies" cause women to fall short of the moral ideal that men ought to strive for' (Kleingeld I993: I42). She cites another passage from the Anthropology to justify her claim. In this passage, Kant notes that a person's exercise of reason can involve deficiencies although the person's 'understanding can be intrinsically sound (without mental deficiencies)' (A 208). Such persons are either naturally or legally incompetent to represent themselves in civil matters requiring a guardian or a representative. It is worth quoting Kant at some length here to understand fully the deficiencies he has in mind:

The (natural or legal) incompetence of an otherwise sound man to use his understanding for himself in civil matters is called tutelage. If he requires a guardian because of his youth, he is said to be a minor (under-age); but if it is because of legal arrangements with regard to civil affairs, he is said to be under legal or civil tutelage. Children are under [natural] tutelage ... A woman ... is under civil tutelage ... It is true that when it comes to talking, woman, by her nature, is sufficiently glib to represent herself and her husband, even in court ..., and so could be literally described as more than competent to speak for herself. But just as it is not woman's role to go to war, so she cannot personally defend her rights and engage in civil affairs for herself. (A 208-9) 
A number of striking observations can be made from this passage. First, Kant does not claim that women are on a par with children in being naturally deficient and incompetent to speak for themselves. Women are simply legally incompetent to do so. Second, Kant does not even claim that women are incapable of representing themselves; he clearly thinks that they are. Rather, women should not do so, just as they should not fight in wars. These remarks about the deficiencies women's exercise of reason involves are not made in a deterministic spirit: for Kant, women are not deficient in that they simply cannot speak for themselves; instead, he thinks that women should not speak for themselves. And this is not enough to undercut Kant's explicit acknowledgement of women's rationality.

Further textual evidence cited for thinking that Kant took women to be innately incapable of rational morality comes from his claims about women scholars (see e.g. Okin I982; Schott I998a). For Kant, intellectual pursuits are not suited for 'a person in whom unconstrained charms should show nothing else than a beautiful nature' and so, such pursuits 'even if a woman should greatly succeed in [them], destroy the merits that are proper to her sex' $\left(O_{78}\right)$. As mentioned earlier, Kant claims a scholarly woman uses books 'in the same way as her watch ... which she carries so that people will see that she has one, though it is usually not running or not set by the sun' $(A$ 307). These remarks supposedly illustrate that for Kant women are by nature morally inferior to men since (he claims) women lack the necessary 'noble' qualities needed for excelling in intellectual pursuits (Mendus I992: I 80). But this conclusion is far from obvious. First, Kant is not claiming that women cannot excel in intellectual endeavours; he clearly recognizes that they can. Again, Kant is saying that women should not pursue intellectual excellence because this will destroy something allegedly valuable in women (though he does not specify what). Second, it is not obvious from these remarks that particular moral deficiencies are innate to women on Kant's view. Quite simply: Kant's claims are not about morality at all.

Other commentators have cited a different passage from the Anthropology in order to show that Kant indeed held there to be a natural basis for women and men's moral differences:

Nature entrusted to woman's womb its dearest pledge, the species, in the form of the foetus ... and in so doing nature was fearful, so to speak, about the preservation of the species, and 
implanted this fear - fear in the face of physical harm and timidity in the face of physical dangers - in woman's nature. Through this weakness woman rightfully demands that man be her protector. (A 306)

Schott, for instance, claims that this very passage shows that for Kant 'woman's lack of self-determination [and autonomy] ... is intrinsic to her nature' (1997: 323; see also Mendus I992: I79). But Schott's view is not substantiated by the cited passage: it addresses physical differences without obviously supporting the view that women are innately incapable of autonomy and self-determination in the morally relevant sense. There is a gap between claims about physical and moral differences: that is, although Kant took women and men to differ physically by nature, this does not yet show that he also took them to differ in their innate moral capacities. Further argument is needed to bridge this gap and make good the claim that Kant took women to be innately morally defective. In a slightly different vein, Kleingeld holds that, not only because women are weak and fearful but also because they are guided by their inclinations, women (for Kant) 'cannot act autonomously or think for themselves' (1993: I37). According to Kleingeld, this is implicit in Kant's claim that women should reign and men should rule in marriage because inclination reigns and reason rules (A 309). Kleingeld further justifies her view by claiming that Kant took women to lack character in the strictest sense (I993: I36) where, for him, this means that one has the disposition to act according to moral principles (A 285). Kant does write in the Anthropology that the 'feminine principle [what the world says is true, and what it does, good] is hard to unite with character in the strict sense of the term' $\left(A_{3} 308\right)$. But he goes on to claim that there have, nevertheless, been 'heroic women' who have 'maintained creditably character' $\left(\begin{array}{l}A \\ 308\end{array}\right)$ - something Kleingeld does not acknowledge. Again, this suggests that Kant did not view women to be incapable of acting according to moral principles. After all, he clearly does not think that women uniformly lack character due to their natural constitution. For Kleingeld's claims to be substantiated, Kant would have had to do so.

Now, one might point out that Kant did (as Mendus and Kleingeld put it) 'identify' women with inclinations. But the gravity of this claim is unclear: first, it is far from clear what this is supposed to mean; second, in claiming that women are so identified, is Kant claiming that women cannot but be identified with inclinations? I take it that in saying women are identified with inclinations, the authors have in mind Kant's 
claims about women acting from a desire to avoid moral ugliness and that 'virtuous actions mean to them such as are morally beautiful' (O 8I). In the previous section, I argued that simply pointing this out is insufficient to show that women are seriously morally deficient in Kant's view. Rather, in order to show that these claims are a source of concern, it must be shown that in Kant's view women cannot but act from inclinations. Without this move, I see no reason to endorse Kleingeld's view that (for Kant) only 'men have the capacity and the obligation to use their reason' (I993: I36; italics mine) when Kant explicitly notes that women are rational beings too. In Kleingeld's defence one might point out that Kant takes 'providence' $\left(O{ }_{8} \mathrm{I}\right)$ to have made women kind and benevolent, suggesting that these qualities are innate to women. But, this does not undermine what I have claimed so far since Kant thinks that we are naturally affected by inclinations irrespective of our sex; just think of the naturally sympathetic man of the Groundwork whose natural inclinations do not render him incapable of going on to act from duty. So, although 'providence' made women benevolent, pointing this out is not enough to justify the view that Kant took women to be innately incapable of rationality.

But how does my argument square with Kant's claim that women have '[n]othing of duty, nothing of compulsion, nothing of obligation!', and that he hardly believes 'the fair sex [to be] capable of principles' (O 8I)? Actually, these claims are entirely consistent with the view that Kant is not making deterministic remarks about women. That is, they are consistent with thinking that women have the capacity to act from duty, although women might fail to exercise this capacity. ${ }^{9}$ For one thing, Kant takes moral guidance and education to be necessary so that one can act dutifully from duty (because doing so is morally required):

[I]n order to bring either a mind that is still uncultivated or one that is degraded onto the track of the morally good in the first place, some preparatory guidance is needed to attract it by means of its own advantage or to alarm it by fear of harm; but as soon as this machinery, these leading strings have had even some effect, the pure moral motive must be brought to bear on the soul. (CPractR I 52; see also $G$ 388)

Acting in accordance with duty must first be made 'a habit', after which the 'attention must be directed' at questioning 'whether the action was also done (subjectively) for the sake of the moral law' so that this produces 'a certain interest in reason's law itself and hence in morally 
good actions' (CPractR I 59-60). However, without such education one is not 'capable of principles' irrespective of one's sex. Furthermore, in the Anthropology Kant writes that it was a

wisdom on nature's part to implant in us the predisposition to sympathy, so that it could handle the reins provisionally, until reason has achieved the necessary strength; that is to say, it was wise of nature to add to our moral incentives to the good the incentive of pathological (sensuous) impulse, to serve as a temporary substitute for reason. (A 253)

Some of us (in fact, many of us according to Kant) do not see dutiful action as morally required because reason has not yet achieved 'the necessary strength'. But this does not preclude reason from being able to gain that strength given the right moral education. So, women may be provisionally incapable of acting from principles until reason comes to achieve this 'necessary strength'. Nonetheless, this does not entail that women are per se incapable of acting from moral principles. Were the worrying claim that women are innately morally deficient in Kant's view to hold, they would have to be per se incapable of acting from moral principles and no amount of moral education could alter this. But, as I see it, there is not sufficient evidence to show that this was Kant's view. Even his claim that women 'do something only because it pleases them' (O 8I; italics mine) is compatible with women having the capacity for morality: qua rational beings, women will have this capacity whether they ever exercise it or not. Even if reason never achieves the necessary strength and even if women (as Kant put it) do something only because it is pleasurable, the potential for reason to achieve the required strength does not disappear.

\section{Women and human dignity}

Earlier I noted that Kant's remarks about women are not deterministic. Rather, they are normative: just as women should not fight in wars, Kant thinks that they should not exercise their rationality because this destroys 'women's charm'. In line with this, Kant writes in the Observations that the moral education of women should 'seek to broaden their total moral feeling and not their memory, and that of course not by universal rules but by some judgement upon the conduct that they see about them' $(O$ 80). He continues stating that women's moral instruction should not involve self-restraint or 'cold and speculative instruction but always feelings' ( $O$ 8I). However, these remarks generate a puzzling inconsistency: Kant urges us to cultivate the use of 
reason in general while not appearing to extend that urge to women's use of reason. What should we make of the view of women's moral education in Kant's Observations that seems blatantly to go against his broader Enlightenment commitments? One might wish to explain away this inconsistency by suggesting that perhaps Kant saw it best to start women off with feelings before they move on to fully deploy their reason. So, although to begin with women's moral education should only involve feelings and not 'speculative instruction', later on women could be introduced to the latter and be shown the value of exercising their rational capacities. ${ }^{\mathrm{IO}}$ However, as far as I can tell, there is no evidence in the Observations (or elsewhere) to back up this suggested dissolution of the inconsistency. I see no reason, then, to accept it and my contention is that Kant's views simply are inconsistent. Still, despite his claim that women's moral instruction should always involve feelings, we should resist the strong feminist condemnation of Kant since his claims about women's moral education do not support the view that women (for him) innately fail to possess the qualities required for morality. Given this, I recommend that Kant's claims about women's moral education, which are inconsistent with some of his other claims about the use of reason, be bracketed off. Looking at what Kant writes about human dignity and women should further convince us of this.

Kant's picture of dignity in the Groundwork is a familiar one. For him, 'the human being and in general every rational being exists as an end in itself, not merely as a means to be used' $(G 428)$. Our actions and dealings with others ought always to reflect this so that we 'use bumanity ... always at the same time as an end, never merely as a means' $(G$ 429). This gives humanity absolute, rather than merely relative, worth. Entities that have relative worth are things, which have a price; those with absolute worth are persons and have 'inner worth, that is, dignity' ( $G$ 435). Now, the ground of dignity is autonomy: that one has the capacity to self-legislate the moral law through reason, not just follow moral rules set by others. As a result, humanity has dignity or absolute worth only 'insofar as it is capable of morality' ( $G 435$ ). Dignity does not depend on whether our actions in fact evoke esteem (have genuine moral worth); what counts is our capacity to act in ways that do.

In order to show that Kant took women to be incapable of morality and so morally deficient, we must demonstrate that he denied women human dignity: if women are incapable of morality, they should have merely relative worth and not be ends in themselves. This comes close 
to the claims made by feminists critical of Kant. For instance, Kant's claim that 'virtuous actions mean to [women] such as are morally beautiful. Nothing of duty, nothing of compulsion, nothing of obligation!' (O 8I) is taken to show that Kant dehumanized women by denying them that on which human dignity and worth are grounded: the capacity for autonomous morality (see e.g. Okin I982: 82). However, in my view, Kant clearly did not deny women dignity and he did not take women to lack absolute worth as ends in themselves. And this undermines the claim that he took women to lack the capacity for morality. Bluntly put: if women were mere things with only relative worth, there would be no need to prohibit treating women in ways that fail to take their humanity into account. But Kant's discussion of marriage and sexual relations suggests precisely the opposite (see $L E$ I $55^{-1} 60$ and $M M$ 276-9). In fact, his entire account of marriage is aimed at safeguarding women so that they are not reduced from persons to things. Kant clearly takes women to have worth qua persons because he thinks that we are prohibited from treating women in ways that violate such worth and make them mere means to be used for men's ends.

Kant's account of marriage hinges on a particular (quite pessimistic) view of sexual desire that is standardly taken to be the following (see e.g. Denis 2002; Herman 2002; Papadaki 2007): sexual desire is inherently problematic in that 'as soon as anyone becomes an object of another's [sexual] appetite, all motives of moral relationship fall away; as object of the other's appetite, that person is in fact a thing' ( $L E{ }_{15} 6$ ). In sexual relationships, one fails to treat the other as an end in themselves because 'sexual impulse is not an inclination that one human has for another, qua human' ( $L E$ I 56) - rather, sexual desire is animalistic. This is problematic for women because ' $[\mathrm{t}] \mathrm{he}$ desire of a man for a woman is not directed to her as a human being; on the contrary, the woman's humanity is of no concern to him' ( $L E$ I 56 ). But sexual desire is also problematic for men: giving into carnal lust defiles one's humanity $\left(M M_{424}\right)$ and, in so doing, men who sexually desire women are also compromising their human dignity. Instead of just accepting the effects of sexual desire, Kant argues for the implementation of certain safeguards. His view is that there ought to be something that protects women from being used as mere means by forcing men to take their humanity into account and that protects men from defiling their humanity through lust. For this end, Kant claims that sexual relations can be safely engaged in only within the confines of a monogamous marriage, where the legally enforced marriage contract ensures the mutual and equal exchange of sexual services. Entering such a contract 
constitutes 'the sole condition' under which humanity is safeguarded and the context of a monogamous, non-adulterous marriage is the only one in which sexual impulses can safely be acted on morally speaking (LE I 59). ${ }^{\text {II }}$

These claims about safeguarding both women's and men's humanity that sexual desire threatens to violate unequivocally show that Kant took both women and men to be ends in themselves. Despite his unquestionable acceptance of the traditional notion of marriage as the cure, his remarks about the need to safeguard women's humanity are a world apart from the charges that he simply took women to lack human dignity, or to be akin to natural serfs or animals (cf. Okin I982: 82; Schröder I997: 296). If women are ends in themselves, they must (on Kant's view) have absolute worth and dignity qua persons - something supported by his comments on marriage. And, as far as I can see, the remarks about women in the Observations and the Anthropology do not undermine this or suggest that Kant denied women's status as ends in themselves. Further, since Kant took women to have absolute worth as persons, I submit, his misguided views about how the use of reason will destroy 'women's charms' can be put to one side. Whatever these purported charms are and whatever their supposed source is, Kant saw women as having the most important and fundamental values of absolute worth and human dignity, which undercuts the claim that Kant took women to be incapable of morality.

\section{Conclusion}

The view that Kant took women to be seriously morally deficient should by now be suspect. In section 2, I argued that it is actually quite difficult to spell out the moral deficiency women on Kant's view supposedly possess. In section 3, I argued that Kant's own remarks about women undermine the most worrying way to understand this deficiency: that Kant took women to be innately incapable of morality. Now, since Kant held certain misguided prejudices and preconceptions about women, his claims about the general use of reason are inconsistent with his claims about women's use of reason. But this is not enough to justify a severe feminist condemnation of Kant and, as I see it, many of Kant's claims that feminist commentators have criticized are not so unsettling after all. What I have argued here should, then, diminish (as Herman puts it) Kant's status as the modern moral philosopher whom feminists find most objectionable. ${ }^{\mathrm{I2}}$

Email: mari.mikkola@hu-berlin.de 


\section{Notes}

I References to Kant's Groundwork of the Metaphysics of Morals (G), Critique of Practical Reason (CPractR), Metaphysics of Morals (MM) and Anthropology from a Pragmatic Point of View $(A)$ will be given to the Akademie edn (vol. 4 for $G$, vol. 5 for CPractR, vol. 6 for $M M$, and vol. 7 for A). References to his Observations on the Feeling of the Beautiful and Sublime (O), Religion within the Limits of Reason Alone $(R)$ and Lectures on Ethics (LE) will be given as page numbers to Kant I960a, I960b, and 1997 respectively.

2 Another reason one might offer for rejecting the suggestion that Kant's view of women had substantially matured from the Observations to his Critical post-I78I period comes from his remarks about women's political rights made in the Metaphysics of Morals published in I797. Kant denies women 'active' citizenship as well as the political rights that go with it $\left(M M{ }^{3} I_{5}\right)$. This is because active citizenship is denied for everyone 'whose preservation in existence (his being fed and protected) depends not on his management of his own business but on arrangements made by another (except the state)' (MM 3 I4). And since women depend on men for the preservation of their existence, they can only be 'passive' citizens. Women are far from being the only group that are relegated to passive citizenship - others include, for instance, barbers and all domestic servants. However, while Kant thinks that they can work towards becoming active, he thinks that this is impossible for women. After all, Kant seems to think that this would require a plainly impossible move: women becoming men. This demonstrates that Kant's worldview did contain some misguided prejudices and preconceptions about women even during his Critical period.

3 Prima facie contrary to this, Steven Sverdlik claims that 'Kant clearly implies that the operation of a desire, whether known or not, negates the presence of moral worth' (200I: 3OI). This comes close to attributing to Kant the 'if inclination, no moral worth' view. However, it is not entirely clear what is meant by 'operation of a desire' and whether this refers to the mere presence of desire or something else. If it just means the presence of desire, then Sverdlik goes against those commentators mentioned who have criticized the absurd view of moral worth. In this case, I take Sverdlik's account of Kant to be wrong since my contention is that Baron et al. are right to claim that Kant did not hold the absurd view of moral worth (more on this shortly). However, if Sverdlik's view is that the operation of desire that compromises moral worth refers to one's action being motivated solely by desire or by a mixture of duty and desire, then his view is not substantially different from those commentators mentioned.

4 Kant makes further remarks that count against the absurd view, which are not noted by Baron. He compares the philosopher to a chemist where the latter arranges experiments in order to distinguish various chemical components and the former in order to distinguish 'the moral (pure) determining ground [of the will] from the empirical' (CPractR 92). The philosopher's experiments are aimed at making the concept of duty vivid, which is why duty and inclination are pitted against one another. But this is not meant to show that Kant in fact took them to be mutually exclusive.

5 Herman's position is not without its critics. Although a number of commentators have broadly accepted her conditions of moral worth, some have argued for further Kantian refinements to these conditions (see e.g. Benson I987; Sorell I998; StrattonLake 2000; Sverdlik 200I; Tannenbaum 2002). Others have taken issue with Herman's (so-called) soft reading of Kant that allows for overdetermined actions to have moral worth (see Jeske I998; Meyers 2008). As one critic puts it, such a soft 
reading is both unnecessary and inaccurate (cf. Meyers 2008). I will not delve into whose account of moral worth is the most faithful one. My aim is not to settle this matter here and for my purposes doing so is unnecessary. This is because I am not aiming to show that women's actions have moral worth in having the conditions that mark such actions from those that do not; I am investigating how we might account for the view that Kant took women's moral conduct to be seriously lacking. I need not settle precisely those conditions that must be satisfied for moral worth since my task is to analyse why it is that women fail to attain moral worth, given that they appear to. And, as far as I can tell, none of the commentators discussed here would find it problematic to claim that women's actions fail to have moral worth, although they might disagree on when exactly the conditions of moral worth are satisfied.

6 One might wonder whether Baron's formulation is strict enough: could one not consistently have a commitment to doing one's duty because one wanted to cheer oneself up or to gain some inner joy in doing so? With this sort of possibility in mind, Korsgaard (I996) claims that moral worth must involve a commitment to doing one's duty because this is morally required, not because one wants to do it or enjoys doing it. In response, Stratton-Lake (2000) argues that formulations like Korsgaard's are still not sufficient: in his view, saying that one must do one's duty because it is morally required, in being the right thing to do, provides no proper motivation for one to do one's duty - more is needed to actually move the agent to act. Settling the matter, however, would take us well beyond the scope of this paper.

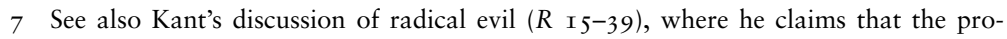
pensity to do evil is inextirpable and definitive of the human moral condition.

8 It is, of course, possible that one's argument contains both a deterministic and a normative premise: it is impossible for women to see their actions as morally required and this is a good thing too. However, my point is that, even though the normative premise does not in itself rule out the deterministic one, Kant's remarks about women do not involve the deterministic premise either alone or in combination with the normative one.

9 Unfortunately, the wording in the original German does not clarify matters: 'Sie werden das Böse vermeiden, nicht weil es unrecht, sondern weil es häßlich ist, und tugendhafte Handlungen bedeuten bei ihnen solche, die sittlich schön sind. Nichts von Sollen, nichts von Müssen, nichts von Schuldigkeit. Das Frauenzimmer ist aller Befehle und alles mürrischen Zwanges unleidlich. Sie thun etwas nur darum, weil es ihnen so beliebt, und die Kunst besteht darin zu machen, daß ihnen nur dasjenige beliebe, was gut ist' $(\$ \S 23 \mathrm{I}-2)$. Note that a sentence feminist commentators have found particularly worrying differs slightly in the English translation from the original German. The claim 'Nothing of duty, nothing of compulsion, nothing of obligation!' (O 8I) reads in German: 'Nichts von Sollen, nichts von Müssen, nichts von Schuldigkeit.' The original German lacks the exclamation mark found in the English translation. And this makes the sentence prima facie much less inflammatory. (Note also that, although 'Frauenzimmer' is nowadays a pejorative used to denote women with 'loose morals', it was not so used in Kant's time.)

Io I am grateful to an anonymous referee for pressing on this point.

I I I noted that this is the standard position. A notable recent exception is that of Allen Wood's view (2008: 224-39). He agrees with the other commentators that sexual desire for Kant threatens to undermine human dignity and worth, and that Kant thought safeguards must be in place to prevent violations of women's humanity. But Wood does not take this to be because Kant thought sexual desire reduces persons to things. Rather, he argues, it is because Kant acknowledged the wider social 
inequalities between women and men of his time, and saw unrestricted sexual relations to have the potential to further compound such inequalities by preventing women from gaining economic, social and legal security. Wood claims that this is why Kant prescribes traditional legally enforced marriage as that which safeguards women's humanity from men's sexual impulses. I must admit that I am not entirely persuaded by Wood's position. However, I must leave a detailed discussion of it for another time.

I2 I am glad to acknowledge the help in writing this paper of Rowan Cruft, Rae Langton, Lina Papadaki, Jenny Saul, Garrath Williams, and the anonymous referees.

\section{References}

Allison, H. E. (1998) 'Morality and Freedom: Kant's Reciprocity Thesis'. In P. Guyer (ed.), Kant's Groundwork of the Metaphysics of Morals: Critical Essays (Landam, MD: Rowman \& Littlefield Publishers), 273-302.

Antony, L. (1998) “ "Human Nature” and its Role in Feminist Theory'. In J. Kourany (ed.), Philosophy in a Feminist Voice (New Haven, CT: Princeton University Press), 63-9I. - (2000) 'Natures and Norms'. Ethics, II I, 8-36.

Antony, L. and Witt, C. (2002) 'Introduction'. In L. Antony and C. Witt (eds), A Mind of one's own (Boulder, CO: Westview Press), pp. ix-Xv.

Baron, M. (1984) 'The Alleged Moral Repugnance of Acting from Duty'. Journal of Philosophy, 8I, I97-220.

— (1995) Kantian Ethics Almost Without Apology. Ithaca, NY: Cornell University Press.

_ (I997) 'Kantian Ethics and Claims of Detachment'. In R. M. Schott (ed.), Feminist Interpretations of Immanuel Kant (University Park, PA: Pennsylvania State University Press), I45-70.

Benson, P. (I987) 'Moral Worth'. Philosophical Studies, 51, 365-82.

Campbell, J. (1983) 'Kantian Conceptions of Moral Goodness'. Canadian Journal of Philosophy, I3, 527-50.

Denis, L. (2002) 'Kant's Ethical Duties and the Feminist Implications'. In S. Brennan (ed.), Feminist Moral Philosophy (Calgary: University of Calgary Press), I 57-87.

Galvin, R. (I99I) 'Does Kant's Psychology of Morality Need Basic Revision?'. Mind, ı००, $22 \mathrm{I}-36$.

Grimshaw, J. (1986) Philosophy and Feminist Thinking. Minneapolis, MN: University of Minnesota Press.

Henson, R. (I979) 'What Kant might have Said: Moral Worth and the Overdetermination of Dutiful Action'. Philosophical Review, 88, 39-54.

Herman, B. (1993) Practice of Moral Judgement. Cambridge, MA: Harvard University Press.

- (2002) 'Could it be Worth Thinking about Kant on Sex and Marriage?'. In L. Antony and C. Witt (eds), A Mind of one's own (Boulder, CO: Westview Press), 53-72.

Jeske, D. (1998) 'A Defense of Acting from Duty'. Journal of Value Inquiry, 32, 6I-74.

Kant, I. (I960a) Observations on the Feeling of the Beautiful and Sublime. Berkeley, CA: University of California Press (German version: Beobachtungen über das Gefübl des Schönen und Erhabenen, in http://www.korpora.org/Kant/aao2/205.html; accessed May 20I0.).

- (1960b) Religion within the Limits of Reason Alone. New York: Harper Torchbooks.

- (1974) Anthropology from a Pragmatic Point of View. The Hague: Martinus Nijhoff.

- (I996a) Critique of Practical Reason. In M. J. Gregor (trans.), Practical Philosophy. Cambridge: Cambridge University Press. 
— (I996b) Groundwork of the Metaphysics of Morals. In M. J. Gregor (trans.), Practical Philosophy. Cambridge: Cambridge University Press.

- (I996c) The Metaphysics of Morals. In M. J. Gregor (trans.), Practical Philosophy. Cambridge: Cambridge University Press.

- (1997) Lectures on Ethics. Cambridge: Cambridge University Press.

Kleingeld, P. (I993) 'The Problematic Status of Gender-Neutral Language in the History of Philosophy: The Case of Kant'. Philosophical Forum, 25, I34-50.

Korsgaard, C. (1996) 'From Duty and for the Sake of the Noble: Kant and Aristotle on Morally Good Action'. In S. Engstrom and J. Whiting (eds), Aristotle, Kant and the Stoics (Cambridge: Cambridge University Press), I03-228.

Mendus, S. (I992) 'Kant: “An Honest But Narrow-Minded Bourgeois”?'. In H. Williams (ed.), Essays on Kant's Political Philosophy (Cardiff: University of Wales Press), I 66-90.

Meyers, C. D. (2008) 'The Virtue of Cold-Heartedness'. Philosophical Studies, I38, 233-44.

Okin, S. M. (I982) 'Women and the Making of the Sentimental Family'. Philosophy and Public Affairs, II, 65-88.

Papadaki, E. (2007) 'Sexual Objectification: From Kant to Contemporary Feminism'. Contemporary Political Thought, 6, 330-48.

Pateman, C. (1988) The Sexual Contract. Stanford, CA: Stanford University Press.

Paton, H. J. (I97I) The Categorical Imperative. Philadelphia, PA: University of Pennsylvania Press.

Plumwood, V. (1993) 'The Politics of Reason: Towards a Feminist Logic'. Australasian Journal of Philosophy, 7I, 436-62.

Rumsey, J. P. (I997) 'Re-visions of Agency in Kant's Moral Theory'. In R. M. Schott (ed.), Feminist Interpretations of Immanuel Kant (University Park, PA: Pennsylvania State University Press), I25-44.

Schott, R. M. (1988) Eros and Cognition. Boston, MA: Beacon Press.

_ ( I997) 'The Gender of Enlightenment'. In R. M. Schott (ed.), Feminist Interpretations of Immanuel Kant (University Park, PA: Pennsylvania State University Press), 3 I9-37.

_ (I998a) 'Feminism and Kant: Antipathy or Sympathy?'. In J. Kneller and S. Axinn (eds), Autonomy and Community (New York: SUNY), 87-100.

— (I998b) 'Kant'. In A. Jaggar and I. M. Young (eds), A Companion to Feminist Philosophy (Malden, MA: Blackwell Publishers), 39-48.

Schröder, H. (I997) 'Kant's Patriarchal Order'. In R. M. Schott (ed.), Feminist Interpretations of Immanuel Kant (University Park, PA: Pennsylvania State University Press), 275-96.

Sedgwick, S. (I990) 'Can Kant's Ethics Survive the Feminist Critique?'. Pacific Philosophical Quarterly, 7I, 60-79.

Sorell, T. (I998) 'Kant's Good Will and our Good Nature'. In P. Guyer (ed.), Kant's Groundwork of the Metaphysics of Morals: Critical Essays (Landam, MD: Rowman \& Littlefield Publishers), 8 I-Ioo.

Stratton-Lake, P. (2000) Kant, Duty and Moral Worth. London: Routledge.

Sverdlik, S. (200I) 'Kant, Nonaccidentalness and the Availability of Moral Worth'. Journal of Ethics, 5, 293-3 I3.

Tannenbaum, J. (2002) 'Acting with Feeling from Duty'. Ethical Theory and Moral Practice, 5, 32I-37.

Wood, A. (I999) Kant's Ethical Thought. Cambridge: Cambridge University Press.

- (2008) Kantian Ethics. Cambridge: Cambridge University Press. 